\section{Legal Cost of Life}

For comparison with these figures it is interesting to note that the maximum award generally accepted by the legal profession for accidental death of a person without dependants is $£ 500$. Should the deceased have dependants the awards vary greatly, each being assessed on the dead person's earnings when he was alive and his normal life expectancy. If a child with meningomyelocele were to be killed in an accident it is unlikely that his estate would receive an award exceeding £125. Awards for injury are much higher. A boy of $16 \frac{1}{2}$ rendered partially quadriplegic by an accident has been awarded damages totalling $£ 62,500 .{ }^{15}$ The awards to the victims of the thalidomide tragedy varied greatly, depending on the disabilities sustained, but the settlement figures ranged from $£ 12,000$ to $£ 25,000$. These figures may be compared with the average cost of saving the life of, and subsequently treating, a patient with meningomyelocele of about $£ 7,250(=£ 3,725,000 \div 500)$.

\section{Conclusions}

Early closure of a meningomyelocele leads to an increase in the number of patients who survive. The cost of maintaining a unit to care for these patients medically, to educate the survivors, and to house them is estimated, as is the future cost. These figures (which are approximate) apply only to England and Wales, and are $£ 1,930,000, £ 1,425,500$, and $£ 370,000$ respectively. The total cost might be expected to rise to at least $f 7 \frac{1}{2}$ million in 10 years. Though not all the possible patients will be referred to a new unit it can be seen that the cost incurred would be far beyond the scope of the funds available to the National Health Service if other and possibly more necessary commitments are to be honoured. If such units were to be established more funds would have to be allocated. Failing this, money from private sources would have to be sought. The Spastics Society's accounts $^{16}$ show that they raise about $£ 2,000,000$ a year. There is a suggestion that such a sum is becoming increasingly difficult to acquire, and as expenses rise the money is financing much less. Such a cost brings into question once again whether early closure is warranted. Ethically many people believe that it is, and therefore the search for funds becomes essential. It would, however, seem to be undesirable to promote a nationwide policy of early closure of meningomyelocele until the funds are available, since to produce survivors who are then uncared for would be worse than to fail to produce survivors at all.

I am grateful to Mr. W. J. W. Sharrard for allowing me to see his management of these children and for his helpful criticism of this paper; to Mr. B. McKibban and Dr. J. Lorber for their comments on this paper; and to Mr. M. A. R. Freeman for his help in its preparation. I must also record my thanks to $\mathrm{Mr}$. Rowland Edwards, of T. V. Edwards $\mathcal{E}$ Co. (Solicitors), who helped me with the legal attitude to these problems.

\section{References}

1 Sharrard, W. J. W., personal communication, 1969.

Central and Scottish Health Services Councils, Surgery for the Newborn. Report of Joint Sub-committee of the Standing Medical Advisory Committees. London, H.M.S.O., 1968.

3 Sharrard, W. J. W., Zachary, R. B., and Lorber, J., Developmental Medicine and Child Neurology, 1967, 9, Suppl. No. 13, p. 35.

4 McKeown, Thomas, Proceedings of the Royal Society of Medicine, 1967, 60, 1219.

${ }^{5}$ Knox, E. G., Developmental Medicine and Child Neurology, 1967, 9, Suppl. No. 13, p. 14.

${ }^{6}$ Henderson, Peter, Hospital Medicine, 1968, 2, 909.

7 Registrar General, Quarterly Returns, 1968, No. 3 (September).

8 General Register Office, Registrar General's Statistical Review of England and Wales for the Year 1968, Part I. Tables, Medical. London, H.M.S.O.
. Thendand 1970.

9 Gehrig, R., and Michaelis, L. S., Paraplegia, 1968, 6, 93.

${ }_{10}$ Lorber, J., personal communication, 1970.

11 Department of Health and Social Security, Hospital Building Procedure Note 6, Appendix 7, Developmental Cost and Area Guide. London, H.M.S.O., 1970 .

12 Department of Health and Social Security, National Health Service Hospital Costing Returns for the Year ending 31st March, 1969. London, H.M.S.O., 1969

${ }^{13}$ Department of Education and Science, Statistics of Education, vol. 5, Introduction, para. 5. London, H.M.S.O., 1969.

14 Office of Health Economics, personal communication, 1970.

15 Kemp, D. A., and Kemp, M. S., with Havery, R. S., The Quantum of Damages, vol. 1, Personal Injury Claims. London, Sweet and Maxwell,

${ }_{16}$ The Spastics Society, Report and Accounts, 1970.

\title{
Nephrotic Syndrome in the Elderly
}

\author{
I. W. FAWCETT, P. J. HILTON, N. F. JONES, A. J. WING
}

British Medical fournal, 1971, 2, 387-388

\section{Summary}

Though the nephrotic syndrome is generally believed to be uncommon in the elderly, patients aged 60 years or more accounted for 25 out of 100 consecutive adult cases.

St. Thomas's Hospital, London S.E.1

I. W. FAWCETT, M.B., M.R.C.P., Senior House Officer, Renal Unit

P. J. HILTON, M.B., M.R.C.P., Senior Medical Registrar

N. F. JONES, M.D., F.R.C.P., Consultant Physician

A. J. WING, D.M., M.R.C.P., Consultant Physician

Six $(24 \%)$ of these had the minimal change lesion, compared with $16 \%$ of the younger adults. The incidence of membranous glomerulonephritis was similar in the two age groups, but proliferative glomerulonephritis was more common in the younger $(29 \%)$ than in the older group $(16 \%)$. Amyloidosis did not have a higher incidence in the higher age group. Five of the elderly patients with minimal change lesion were treated with prednisonein four a complete remission from the nephrotic syndrome followed, while the fifth patient's course is unknown.

These results suggest that, when the patient's other circumstances allow, the nephrotic syndrome in an elderly patient should be investigated and managed as in younger age groups. 


\section{Introduction}

The nephrotic syndrome in the elderly has received relatively little attention and is generally believed to be uncommon. Our experience is different, and in this hospital patients over the age of 60 account for about a quarter of all adults with nephrotic syndrome. In this paper we describe 25 cases of the nephrotic syndrome in patients aged 60 years or more who were seen at this hospital over the six-year period 1965-70. Needle biopsies of the kidney were obtained in 22 of the 25 patients and the value of investigating the nephrotic syndrome in elderly patients is discussed.

\section{Results and Discussion}

In the period 1 January 1965 to 31 December 1970100 patients aged 15 or more presented with an unexplained nephrotic syndrome. This does not include those previously known to have renal diseases recognized as causes of nephrotic syndrome. Thus a patient with known chronic glomerulonephritis who became nephrotic during this period would be excluded from this series. Patients with diabetes are also excluded.

Causes of Nephrotic Syndrome in Adults (over 15 Years) 1965-70

\begin{tabular}{|c|c|c|c|c|c|c|}
\hline \multirow{2}{*}{$\begin{array}{l}\text { Age in } \\
\text { Years }\end{array}$} & \multicolumn{3}{|c|}{ Glomerulonephritis } & \multirow{2}{*}{ Amyloid } & \multirow{2}{*}{$\begin{array}{c}\text { Other } \\
\text { Diseases* }\end{array}$} & \multirow[b]{2}{*}{ Total } \\
\hline & $\begin{array}{c}\text { Minimal } \\
\text { Change }\end{array}$ & $\begin{array}{l}\text { Membra- } \\
\text { nous }\end{array}$ & $\begin{array}{c}\text { Prolifer- } \\
\text { ative }\end{array}$ & & & \\
\hline $\begin{array}{l}>60 \\
15-59\end{array}$ & $\begin{array}{r}6(24) \\
12(16)\end{array}$ & $\begin{array}{r}5(20) \\
20(27)\end{array}$ & $\begin{array}{r}4(16) \\
22(29)\end{array}$ & $\begin{array}{r}3(12) \\
13(17)\end{array}$ & $\begin{array}{l}7(28) \\
8(11)\end{array}$ & $\begin{array}{l}25 \\
75\end{array}$ \\
\hline
\end{tabular}

Percentages are given in parentheses.

Including three patients over 60 and one patient under 60 who did not have renal biopsy.

The Table shows the incidence of the various causes of the nephrotic syndrome in patients aged 60 or more as compared with younger adults. The data were not submitted to formal statistical analysis as the numbers of patients with each disease in the older age group are small. The incidence of membranous glomerulonephritis was similar in the two age groups, but proliferative glomerulonephritis had a higher incidence in the younger group. It is apparent that the minimal change lesion is an important cause of nephrotic syndrome in the elderly as well as in younger patients. It is also noteworthy that the incidence of amyloidosis in this series was not higher in the older than in the younger age group. Two elderly patients with membranous glomerulonephritis were found to have carcinoma of the bronchus, an association that has been noted previously. ${ }^{1}$ Details of these patients will be included in another report.

A typical instance of the nephrotic syndrome in the elderly is presented in the following case report.

\section{CASE REPORT}

A 77-year-old man was referred by his general practitioner for advice on management of a nephrotic syndrome which had developed over the preceding two months. He also had painful osteoarthritis of both hips which restricted his activities, and the development of dependent oedema made him housebound. There was no previous history of renal disease.

On admission to hospital he had massive oedema of the legs and lower trunk and heavy proteinuria. His blood pressure was 190/100 and the jugular venous pressure was not raised. Investigations showed: plasma albumin $2.3 \mathrm{~g} / 100$ and urinary protein excretion $5-10 \mathrm{~g} / 24$ hours. The blood urea was $100 \mathrm{mg} / 100 \mathrm{ml}$, plasma creatinine $1.4 \mathrm{mg} / 100 \mathrm{ml}$, and the creatinine clearance $45 \mathrm{ml} / \mathrm{min}$. A throat swab was sterile and the antistreptolysin $\mathrm{O}$ titre less than 50 Todd units. Serum immunoglobulins IgG and IgM were normal but IgA was raised to $700 \mathrm{mg} / 100 \mathrm{ml}$. An intravenous pyelogram showed no abnormality.

A needle biopsy of the kidney showed on light microscopy considerable ischaemic nephrosclerosis with an equivocal increase in mesangial cellularity, but no other sign of primary glomerular disease. Electron microscopy revealed foot process fusion but no other pathology in those glomeruli not involved in nephrosclerotic lesions.

The proteinuria was selective, the IgG to albumin clearance ratio being $0 \cdot 11$. Because of the biopsy and protein clearance studies it was felt reasonable to give steroid therapy a trial. Within two weeks of starting prednisone $60 \mathrm{mg} /$ day the urine was protein-free and a complete remission of the nephrotic syndrome followed (see Chart).

Up to the time of writing he has remained free of oedema and without proteinuria for seven months and has resumed his previous useful level of activity.
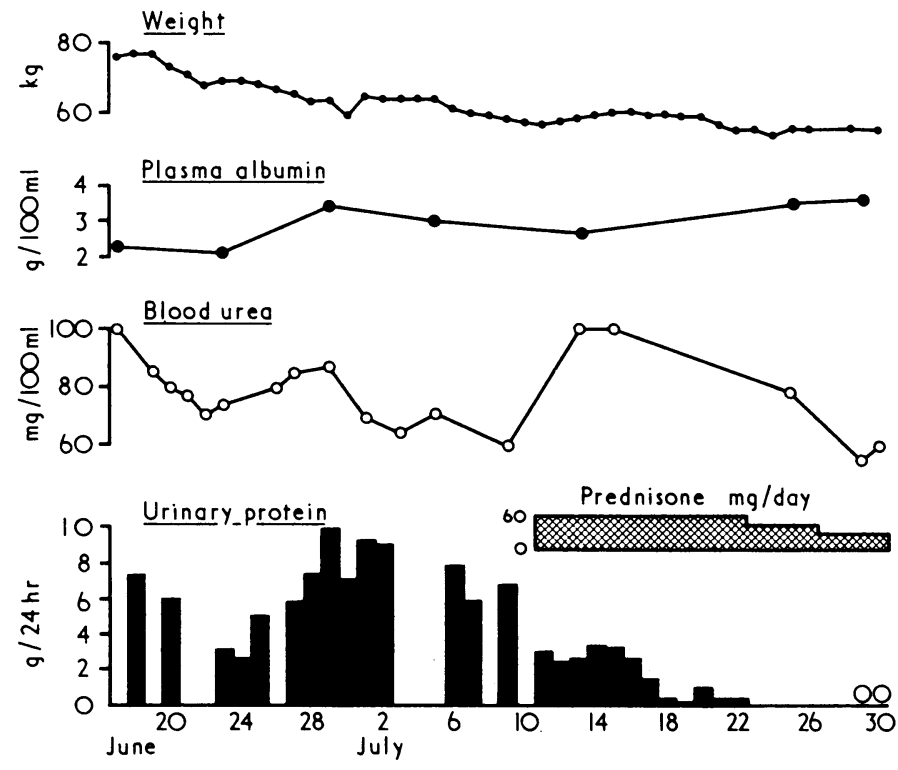

Course of the nephrotic syndrome in a man aged 77 treated with prednisone. Renal biopsy showed the minimal change lesion and the proteinuria was selective.

We have often met considerable uncertainty in general practitioners and consultants about the value of investigating the nephrotic syndrome in elderly patients. Our experience suggests that it is of value to investigate such patients, unless other factors make this unreasonable. Moreover, we suggest that elderly patients who become oedematous are not infrequently treated at home with diuretics and are not investigated, so that the incidence of the nephrotic syndrome in this age group in a hospital series may tend to be an underestimation.

' Lee, J. C., Yamauchi, H., and Hopper, J., Annals of Internal Medicine, 